JURNAL NOMINAL / VOLUME IV NOMOR 1 / TAHUN 2015

\title{
PENGARUH BUDAYA ORGANISASI DAN GAYA KEPEMIMPINAN TERHADAP KINERJA PEGAWAI BAGIAN KEUANGAN ORGANISASI SEKTOR PUBLIK DENGAN MOTIVASI KERJA SEBAGAI VARIABEL INTERVENING
}

(Studi Kasus Pada Pegawai Pemerintah Kota Tasikmalaya)

\author{
Evi Wahyuni \\ Alumni Prodi Akuntansi Universitas Negeri Yogyakarta \\ evi.w26@gmail.com
}

\begin{abstract}
Abstrak: Pengaruh Budaya Organisasi dan Gaya Kepemimpinan terhadap Kinerja Pegawai Bagian Keuangan Organisasi Sektor Publik dengan Motivasi Kerja sebagai Variabel Intervening (Studi Kasus pada Pegawai Pemerintah Kota Tasikmalaya). Penelitian ini bertujuan untuk mengetahui (1) pengaruh Budaya Organisasi terhadap Kinerja Pegawai (2) pengaruh Gaya Kepemimpinan terhadap Kinerja Pegawai (3) pengaruh Budaya Organisasi terhadap Kinerja Pegawai melalui Motivasi Kerja; (4) pengaruh Gaya Kepemimpinan terhadap Kinerja Pegawai melalui Motivasi Kerja. Populasi penelitian ini adalah pegawai bagian keuangan yang bekerja di dinas-dinas Pemerintah Kota Tasikmalaya yang berjumlah 96 orang. Teknik pengambilan data menggunakan populasi. Teknik analisis data yang digunakan dalam penelitian adalah uji regresi linier sederhana dan analisis jalur.

Hasil penelitian menunjukkan terdapat pengaruh positif Budaya Organisasi terhadap Kinerja Pegawai dengan $\mathrm{R}$ Square sebesar 0,326 terdapat pengaruh positif Gaya Kepemimpinan terhadap Kinerja Pegawai dengan R Square sebesar 0,364. Hasil penelitian Budaya Organisasi terhadap Kinerja Pegawai melalui Motivasi Kerja positif dengan pengaruh mediasi koefisien mediasi 0,315, dan terdapat pengaruh positif Gaya Kepemimpinan terhadap Kinerja Pegawai yang melalui Motivasi Kerja dengan koefisien mediasi 0,251 .
\end{abstract}

Kata Kunci: Budaya Organisasi, Gaya Kepemimpinan, Motivasi Kerja, Kinerja Pegawai

Abstract: The Effect of Organizational Culture and Leadership Style on The Performance of Financial Division Employees of Public Sector Organization Using Working Motivation as Intervening Variable (A Case Study of Tasikmalaya Municipal's Employees). This research aims to determine (1) the influence of organizational culture on employee performance (2) the influence of leadership style on employee performance (3) the influence of organizational culture on employee performance through work motivation; (4) the effect of leadership style on employee performance through motivation Kerja.Populasi this study were employees who worked in the finance department offices Tasikmalaya City Government, amounting to 96 people. Using population data retrieval techniques. Data analysis techniques used in the study is a simple linear regression and path analysis.

The results showed a positive influence organizational culture on employee performance with $R$ Square of 0.326, there is a positive effect of leadership style on employee performance with $R$ Square of 0.364. Organizational Culture research results on employee performance through positive work motivation mediation effect of mediation coefficient 0.315 , and there is a positive effect of leadership style on employee performance through motivation mediation Working with the coefficient 0.251 .

Keywords: Organizational Culture, Leadership Style, Work Motivation, Employee Performanc 


\section{JURNAL NOMINAL / VOLUME IV NOMOR 1 / TAHUN 2015}

\section{PENDAHULUAN}

Pegawai bagian keuangan dalam organisasi sektor publik mempunyai tugas pokok melaksanakan penyusunan rencana kegiatan pengkoordinasian, pembinaan, pengendalian dan pemberian bimbingan di bidang pengelolaan administrasi dan pelaporan tanggung jawaban keuangan. Pegawai bagian keuangan akan membantu dalam menyediakan informasi yang digunakan untuk mengambil keputusan. Informasi tersebut bisa berupa informasi keuangan maupun non keuangan yang dapat digunakan oleh organisasi, pemerintah pusat dan masyarakat untuk menilai kinerja organisasi tersebut. Hal ini dapat digunakan oleh organisasi, pemerintah pusat dan masyarakat untuk menilai kinerja organisasi tersebut. Kinerja pegawai bagian keuangan memiliki peran penting bagi organisasi. Jika mereka telah melaksanakan tugas-tugasnya dengan baik dan benar maka akan dihasilkan informasi keuangan yang baik, transparan, dan akuntabel yang akan berpengaruh positif terhadap kinerja organisasi sektor publik. Hal tersebut sesuai dengan prinsip pelayanan publik yang baik yaitu tranparansi dan akuntabilitas.

Budaya organisasi pada sektor publik lebih menekankan kepada pelayanan publik karena berpengaruh dalam menciptakan pelayanan publik yang baik. Salah satu budaya organisasi yakni kompetensi secara pribadi dari pegawai. Pelayanan yang diberikan kepada publik merupakan bentuk output yang selama ini diproses oleh pegawai dan pekerja yang berada dalam organisasi. Dengan adanya interaksi atau komunikasi antar pegawai maupun interaksi komunikasi antara pegawai dengan publik, maka akan memupuk budaya organisasi yang baik. Pelayanan yang baik tidak lagi menjadi kewajiban melainkan sudah menjadi kebiasaan atau budaya.

Gaya kepemimpinan merupakan faktor kunci di dalam organisasi sektor publik. Seorang pemimpin dituntut untuk mampu membawa dan memaksimalkan organisasi yang dipimpinnya untuk memberikan pelayanan yang berkualitas dan mencapai kepuasan masyarakat yang optimal. Gaya kepemimpinan merupakan cara pemimpin mempengaruhi pegawai untuk dapat bekerja lebih baik lagi dalam rangka mencapai tujuan organisasi karena pada hakikatnya organisasi sektor publik terbentuk untuk memberikan pelayanan kepada masyarakat. Suatu organisasi akan berjalan lancar dalam mencapai tujuan organisasi yang telah ditetapkan sangat dipengaruhi oleh faktor kepemimpinan. Oleh karena itu pemimpin selalu menjadi fokus evaluasi sebagai gambaran penilaian terhadap keberhasilan sebuah organisasi.

Motivasi kerja di dalam organisasi sektor publik lebih diarahkan untuk memberikan kekuatan dan dorongan dalam diri seorang pegawai yang akan 


\section{JURNAL NOMINAL / VOLUME IV NOMOR 1 / TAHUN 2015}

mempengaruhi pelaksanaan tugas dan tanggung jawabnya terhadap pelayanan publik. Pemberian motivasi yang tepat kepada para pegawai akan menghasilkan kinerja yang optimal untuk melayani publik.

Penelitian M. Hanif Al Rizal (2012) menunjukkan bahwa budaya organisasi memiliki pengaruh positif dan signifikan terhadap kinerja pegawai. Dalam hasil penelitian tersebut dinyatakan bahwa budaya dalam suatu organisasi berkembang dengan kuat, sehingga dalam kondisi demikian, setiap pegawai mengetahui dengan baik tujuan organisasi yang akan dicapainya serta mempengaruhi produktivitas kerja di dalam organisasi. Penelitian selanjutnya oleh Iqbal Nazili (2012) menunjukkan gaya kepemimpinan dengan motivasi kerja sebagai variabel intervening berpengaruh positif dan signifikan terhadap kinerja karyawan. Penelitian yang lain oleh Rani Mariam (2009) yang menunjukkan bahwa budaya organisasi dan gaya kepemimpinan mempunyai pengaruh positif dan signifikan terhadap kepuasan kerja dalam meningkatkan kinerja karyawan.

Penelitian mengenai faktor yang mempengaruhi kinerja pegawai, seperti budaya organisasi dan gaya kepemimpinan dengan motivasi kerja sebagai variabel intervening akan dilakukan di Pemerintahan Kota Tasikmalaya. Dilihat dari penilaian kinerja unit kerja pelayanan publik (UKPP) bagian pertanian tingkat Provinsi Jawa Barat tahun 2013, Pemerintahan Kota Tasikmalaya merupakan salah satu kota yang memiliki kinerja organisasi publik yang baik. Di usianya yang masih muda, UPTD Dinas Pertanian dan Kehutanan Kota Tasikmalaya telah menjadi salah satu unit pelayanan publik yang membanggakan bagi masyarakat dan Pemerintah Kota Tasikmalaya, Piagam abdi bakti tani tingkat nasional tahun 2011 merupakan salah satu bentuk pengakuan atas kinerja UPTD yang memuaskan. Informasi lain yang didapat dari Kepala Bagian Keuangan di Sekretariat daerah Pemerintah Kota Tasikmalaya menyatakan bahwa untuk laporan keuangan Pemerintah Kota Tasikmalaya tahun 2011, BPK memberikan penilaian Wajar Dengan Pengecualian. Hal ini mengindikasikan bahwa dalam laporan keuangan terdapat catatan yang perlu diperhatikan. Adapun informasi mengenai kinerja pegawai diperoleh dari Kasubag Kepegawaian Dinas Pendapatan Daerah Pemerintah Kota Tasikmalaya yang menyatakan bahwa kinerja pegawai belum optimal sesuai dengan yang diharapkan karena kendala waktu dan kapabilitas pegawai yang terbatas.

Budaya organisasi di Pemerintahan Kota Tasikmalaya tertanam dengan baik. Hal ini ditunjukkan diantaranya dengan adanya sikap yang terbentuk seperti sebuah tim dan toleransi yang kuat diantara para pegawai, tidak adanya pembeda atau kasta, dan hubungan yang harmonis diantara pimpinan 


\section{JURNAL NOMINAL / VOLUME IV NOMOR 1 / TAHUN 2015}

dan pegawai melalui kegiatan-kegiatan di luar organisasi yang sudah menjadi bagian dari program seperti outbond dan rekreasi. Toleransi yang kuat juga ditunjukkan ketika salah satu pegawai pada sub bagian tertentu tidak masuk kerja dengan catatan adanya alasan yang bisa diterima maka pegawai yang lain pada sub bagian tersebut memberikan toleransi dan ikut bertanggungjawab dalam menyelesaikan tugas pegawai yang tidak masuk. Pimpinan tidak mengenal istilah bawahan terhadap pegawainya karena semua pegawai adalah mitra kerja yang berarti memiliki kesetaraan menjalankan kepentingan bersama, dan kedekatan yang terjalin diantara pimpinan dan pegawai baik didalam maupun diluar pekerjaan. Namun, semua yang telah diuraikan mengenai budaya organisasi tersebut masih terdapat permasalahan diantaranya para pegawai masih belum bisa menyesuaikan pribadinya dengan kebudayaan organisasi yang ada seperti absennya pegawai ketika apel pagi dan adanya pegawai yang tidak menjunjung tinggi arti tegur sapa antar pegawai.

Teori Path Goal yang dikemukakan oleh Robert House dalam Miftah Toha (2007: menyatakan bahwa kepemimpinan suportif mempunyai kesediaan untuk menjelaskan sendiri, bersahabat, mudah didekati, dan mempunyai perhatian kemanusiaan yang murni terhadap para bawahannya. Gaya kepemimpinan di
Pemerintahan Kota Tasikmalaya berpola Gaya Kepemimpinan suportif yang ditunjukkan dengan adanya sikap kepedulian dari pimpinan terhadap pegawai seperti, rutinitas yang dilakukan oleh pimpinan dalam mengawasi pegawainya setiap hari dalam rangka terwujudnya kedekatan sehingga tercapainya peningkatan kinerja. Pengawasan yang dilakukan oleh pimpinan terhadap pegawai disertai dengan komunikasi yang baik sehingga menciptakan keakraban yang baik pula. Namun gaya kepemimpinan seperti itu memiliki beberapa kelemahan, misalnya sikap pegawai yang kurang menghormati pimpinan baik dari segi perkataan maupun perbuatan, kurangnya rasa takut seorang pegawai ketika melakukan suatu kesalahan karena timbulnya dugaan bahwa pimpinan tidak akan memberikan sanksi berupa teguran atau tindakan.

Motivasi Kerja di Pemerintahan Kota Tasikmalaya dilakukan dengan cara memberikan motivasi positif dan membentuk pribadi teladan pada pimpinan. Motivasi positif dilakukan dengan cara memberikan pujian, penghargaan, dan dukungan moril. Pribadi teladan dapat ditanamkan dalam rangka mempengaruhi pegawai seperti dengan memberikan contoh yang baik seperti membuang sampah pada tempatnya, bekerja sungguh-sungguh saat jam kerja, tidak pernah telat masuk kerja, pulang sesuai jam yang sudah ditentukan, shalat tepat waktu pada jam istirahat, berkata sopan dan sesuai 


\section{JURNAL NOMINAL / VOLUME IV NOMOR 1 / TAHUN 2015}

etika, berpenampilan baik, menyelesaikan pekerjaan sesuai waktu yang ditentukan, dan lain-lain. Cara ini dianggap tepat karena sikap atau tindakan mampu memberikan pengaruh yang lebih kuat untuk memberikan dorongan positif terhadap kinerja pegawai. Namun, terdapat permasalahan yang menyebabkan motivasi kerja dari pimpinan kadang kurang berpengaruh dan tidak sesuai dengan yang diharapkan. Permasalahannya adalah karakter dan kapabilitas pegawai yang terbatas sehingga tidak mampu mencapai hasil kerja yang maksimal meskipun pimpinan telah memberikan motivasi kerja yang baik.

Berdasarkan uraian di atas tentang Kinerja Pegawai, Budaya Organisasi, Gaya Kepemimpinan dan Motivasi Kerja di Pemerintah Kota Tasikmalaya penulis tertarik untuk melakukan penelitian dengan judul "Pengaruh Budaya Organisasi dan Gaya Kepemimpinan terhadap Kinerja Pegawai Bagian Keuangan Organisasi Sektor Publik dengan Motivasi Kerja Sebagai Variabel Intervening (Studi Kasus Pada Pegawai Pemerintah Kota Tasikmalaya)".

\section{METODE PENELITIAN}

\section{Desain Penelitian}

Menurut Sugiyono (2012: 37) jenis penelitian ini dilihat dari sifat-sifat masalahnya merupakan penelitian kausal komparatif yang menunjukkan hubungan sebab akibat antara satu variabel dengan variabel lainnya. Metode pengumpulan data dilakukan dengan menggunakan pendekatan studi kasus. Studi kasus dilakukan pada Dinas Pendapatan Daerah; Dinas Sosial, Tenaga kerja dan Transmigrasi; Dinas Pendidikan; Dinas Kesehatan; Dinas Perhubungan, Komunikasi dan Informasi; Dinas Pekerjaan Cipta Karya dan Tata Ruang; Dinas Pertanian, Perikanan dan Kehutanan; Dinas Kebudayaan, Pariwisata, Pemuda dan Olahraga; Dinas Koperasi UMKM, Perindustrian dan Perdagangan yang ada di Pemerintah Kota Tasikmalaya. Peneliti membagikan kuisioner kepada pegawai bagian keuangan yang ada di dinas tersebut.

\section{Tempat dan Waktu Penelitian}

Penelitian ini dilakukan di Pemerintahan Kota Tasikmalaya. Waktu yang diperlukan untuk menyelesaikan penelitian ini adalah selama dua bulan, berlangsung dari bulan Oktober hingga November 2014.

\section{Definisi Operasional Variabel Penelitian}

a. Variabel Dependen (Y)

Variabel terikat merupakan variabel yang dipengaruhi atau yang menjadi akibat karena adanya variabel bebas (Sugiyono, 2012:39). Variabel terikat dalam penelitian ini adalah Kinerja Pegawai bagian keuangan organisasi sektor publik pada Pemerintah Kota Tasikmalaya. 


\section{JURNAL NOMINAL / VOLUME IV NOMOR 1 / TAHUN 2015}

Kinerja Pegawai bagian keuangan adalah suatu hasil pencapaian kualitas dan kuantitas kerja pegawai bagian keuangan yang bekerja di dinas di Pemerintah Kota Tasikmalaya dalam melaksanakan tanggung jawabnya kepada organisasi dengan dipengaruhi oleh faktor internal dan faktor eksternal dalam pelaksanaannya. Instrumen yang digunakan untuk mengetahui kualitas Kinerja Pegawai bagian keuangan pada Pemerintah Kota Tasikmalaya yaitu 18 item pernyataan yang terdiri dari 4 indikator dikutip dari Suyadi Prawirosentono (2008) yaitu efektivitas dan efisiensi, tanggung jawab, disiplin dan inisiatif.

b. Variabel Independen (X)

Variabel bebas merupakan variabel yang mempengaruhi atau yang menjadi sebab perubahannya atau timbulnya variabel terikat (Sugiyono, 2012:39). Variabel bebas dalam penelitian ini adalah Budaya Organisasi dan Gaya Kepemimpinan.

Budaya Organisasi terhadap Kinerja Pegawai bagian keuangan organisasi sektor publik yaitu 24 item pernyataan yang terdiri dari 10 indikator dan diambil dari Robbins (1996) dalam Pabundu (2006: 10) yaitu inisiatif individual, toleransi terhadap tindakan resiko, pengarahan, integrasi, dukungan pimpinan, kontrol, identitas, sistem imbalan, toleransi terhadap konflik, dan pola komunikasi.

Gaya kepemimpinan adalah suatu kombinasi dari pengetahuan, keterampilan, dan prinsip yang menghasilkan perilaku dan strategi yang digunakan oleh seorang pemimpin dalam mengarahkan pegawai agar semua anggota organisasi mengahasilkan kinerja terbaiknya sehingga tujuan organisasi terwujud. Instrumen yang digunakan untuk mengukur pengaruh Gaya Kepemimpinan terhadap Kinerja Pegawai bagian keuangan organisasi sektor publik yaitu 15 item pertanyaan yang terdiri dari indikator dan dikutip dari Veithzal dan Mulyadi (2013: 21) yaitu tingkat energi dan toleransi terhadap stres, rasa percaya diri, integritas, motivasi kekuasaan, orientasi pada keberhasilan, dan kebutuhan afiliasi yang rendah.

Motivasi Kerja adalah kekuatan yang timbul dari sebuah keinginan atau adanya dorongan untuk mencapai sebuah keinginan yang membuat diri seseorang melakukan rencana, membuat konsep, menyusun strategi, dan mengimplementasikannya melalui tindakan dengan penuh semangat yang tinggi dalam rangka mencapai keinginannya tersebut. Instrumen yang digunakan untuk mengukur pengaruh Motivasi Kerja terhadap Kinerja 


\section{JURNAL NOMINAL / VOLUME IV NOMOR 1 / TAHUN 2015}

Pegawai bagian keuangan organisasi sektor publik yaitu 15 item pernyataan yang terdiri dari 4 indikator dan dikutip dari Daft (2010) terdiri dari kebutuhan berprestasi, kebutuhan berafiliasi, dan kebutuhan kekuasaan.

\section{Populasi}

Populasi merupakan wilayah generalisasi yang terdiri atas objek/subjek yang mempunyai kualitas dan karakteristik tertentu yang ditetapkan oleh peneliti untuk dipelajari kemudian ditarik kesimpulannya (Sugiyono, 2012:80). Populasi dalam penelitian ini adalah seluruh pegawai bagian keuangan yang bekerja di dinas-dinas Pemerintah Kota Tasikmalaya. Jumlah pegawai bagian keuangan seluruhnya sebanyak 96 pegawai.

\section{Teknik Pengumpulan Data}

Jenis data yang digunakan dalam penelitian ini adalah data primer, yaitu data yang dikumpulkan secara langsung dari lapangan penelitian melalui kuesioner. Teknik kuesioner merupakan teknik pengumpulan data yang dilakukan dengan cara memberi seperangkat pertanyaan atau pernyataan tertulis kepada responden untuk dijawab (Sugiyono, 2012:142). Kuesioner didistribusikan secara langsung kepada responden. Dua minggu setelah dikirimkan kemudian kuesioner diambil. Pengiriman dan pengambilan kuesioner yang dilakukan secara langsung bertujuan untuk memperoleh tingkat pengembalian kuesioner yang tinggi. Kuesioner terdiri dari 2 bagian yaitu bagian pertama mengenai identitas responden, dan bagian kedua berisi daftar pertanyaan mengenai Kinerja Pegawai bagian keuangan pada Pemerintahan Kota Tasikmalaya, Budaya Organisasi, Gaya Kepemimpinan, dan Motivasi Kerja.

\section{Teknik Analisis Data}

a. Uji Validitas dan Reliabilitas

Instrumen yang valid adalah alat ukur yang digunakan untuk mendapatkan data (mengukur) itu valid (Sugiyono, 2012:121). Uji validitas merupakan suatu prosedur yang dilakukan oleh peneliti untuk mengetahui apakah pertanyaan atau pernyataan yang digunakan dalam kuesioner dapat mengukur dengan tepat atau tidak.

Teknik korelasi product moment dari Karl Person digunakan untuk menguji validitas butir pernyataan. Berdasarkan data yang diperoleh nilai $\mathrm{r}_{\text {hitung dari masing-masing variabel }}$ Kinerja Pegawai bagian keuangan, Budaya Organisasi, Gaya Kepemimpinan, dan Motivasi kerja. Dari variabel Kinerja Pegawai bagian keuangan terdapat 1 butir pernyataan yang tidak valid yaitu butir no 8 , dari variabel Budaya Organisasi terdapat 1 


\section{JURNAL NOMINAL / VOLUME IV NOMOR 1 / TAHUN 2015}

butir pernyataan yang tidak valid yaitu butir no 3, dari variabel Gaya Kepemimpinan terdapat 2 butir pernyataan yang tidak valid yaitu butir no 11 dan 15, dan dari variabel Motivasi kerja terdapat 2 butir pernyataan yang tidak valid yaitu butir no 2 dan 11. Butirbutir yang tidak valid tersebut memiliki $\mathrm{r}_{\text {hitung }}$ lebih kecil dari $\mathrm{r}_{\text {tabel }} 0,361$, sementara butir-butir yang lain mempunyai $r_{\text {hitung }}$ lebih besar dari $r_{\text {tabel }}$ dan dinyatakan valid serta dapat digunakan untuk penelitian selanjutnya.

Instrumen yang reliabel berarti instrumen yang jika digunakan beberapa kali untuk mengukur objek yang sama, akan menghasilkan data yang sama (Sugiyono, 2012:122). Hasil pengukuran dapat dipercaya bila dalam beberapa kali pelaksanaan pengukuran terhadap kelompok subjek yang sama diperoleh hasil yang relatif sama, selama aspek yang diukur tidak berubah. Uji reliabilitas pada penelitian ini menggunakan metode alpha Cronbach untuk menentukan apakah setiap instrumen reliabel atau tidak. Pengukuran ini menggunakan uji statistik Cronbach Alpha ( $\alpha)$. Suatu konstruk atau variabel dikatakan reliabel jika memberikan nilai Cronbach Alpha > 0,60 (Nunnally, dalam Imam Ghozali, 2011:34). Untuk mengukur reliabilitas instrumen dalam penelitian ini menurut
Imam Ghozali (2011: 48) digunakan pengukuran dengan cara One shot atau pengukran sekali saja. Pengukurannya hanya sekali saja dan kemudian hasilnya dibandingkan dengan pertanyaan lain atau mengukur korelasi antar jawaban $\begin{array}{llll}\text { pertanyaan. } & \text { SPSS Statistics } & 13.0\end{array}$ memberikan fasilitas untuk mengukur reliabilitas dengan uji statistik Cronbach Alpa $(\alpha)$. Berdasarkan hasil uji reliabilitas menunjukkan bahwa semua item pernyataan dari empat variabel yang diteliti adalah reliabel karena mempunyai nilai Cronbach Alpha >0,60 sehingga kuesioner dari variabel tersebut dapat digunakan untuk analisis data.

b. Statistik Deskriptif

Analisis statistik deskriptif digunakan untuk mendeskripsikan atau memberikan gambaran terhadap objek yang diteliti melalui data sampel sebagaimana adanya tanpa melakukan analisis dan membuat kesimpulan yang berlaku secara umum (Sugiyono, 2012:147). Data yang dilihat adalah dari rata-rata (mean), standar deviasi, nilai maksimum, nilai minimum, dan jumlah data penelitian. Penelitian tabel distribusi frekuensi dilakukan dengan menentukan kelas interval, menghitung rentang data, dan menentukan panjang kelas, untuk menentukannya menggunakan rumus Sturges.

c. Uji Prasyarat Analisis 


\section{JURNAL NOMINAL / VOLUME IV NOMOR 1 / TAHUN 2015}

1) Uji linearitas

Uji linearitas digunakan untuk melihat apakah spesifikasi model yang digunakan sudah benar atau tidak (Imam Ghozali, 2011:166). Uji linearitas memberikan informasi apakah model empiris sebaiknya linear, kuadrat atau kubik. Dengan menggunakan SPSS Statistics versi 13.

Berdasarkan hasil uji linearitas hubungan antara variabel bebas dengan variabel terikat tersebut bersifat linear dilihat dari nilai signifikansi yang semuanya di atas 0,05. Pada variabel Budaya Organisasi nilai signifikansi sebesar 0,260 di atas 0,05 maka linear, Gaya Kepemimpinan sebesar 0,102 di atas 0,05 maka linear dan Motivasi Kerja sebesar 0,084 di atas 0,05 maka dinyatakan linear.

2) Uji Asumsi Klasik

Uji asumsi klasik merupakan tahapan yang harus dilakukan sebelum melakukan uji analiis regresi. Model regresi harus bebas dari uji linearitas dan uji asumsi klasik yaitu, uji multikolinearitas dan uji heteroskedastisitas.

Uji multikolinearitas digunakan sebagai langkah untuk menguji apakah terdapat multikolinearitas antar variabel independen. Tidak ditemukan korelasi diantara variabel independen merupakan kriteria dari model regresi yang baik. Menurut Imam Ghozali (2011:105) jika variabel independen saling berkorelasi, maka variabel-variabel ini tidak ortogonal. Cara untuk mendeteksi ada atau tidaknya multikolinearitas di dalam model regresi yang dapat dilihat dari nilai variance inflation factor (VIF). Hasil uji multikolinearitas tersebut diketahui nilai tolerance $\leq 0,1$ dan VIF $\geq 10$ berarti dapat disimpulkan bahwa tidak terdapat gejala multikolinearitas dalam model regresi tersebut.

Uji heterokedastisitas bertujuan untuk menguji apakah dalam regresi terjadi ketidaksamaan variance dari residual satu pengamatan ke pengamatan lain. Jika variance dari residual satu pengamatan ke pengamatan lain tetap maka dinamakan homoskedastisitas dan jika berbeda disebut heteroskodestisitas. Model regresi yang baik adalah homokosdestisitas atau tidak terjadi heteroskedastisitas (Imam Ghozali, 2011: 139).

Penelitian ini melihat Grafik Plot antara nilai prediksi variabel terikat (dependen) yaitu ZPRED dengan residualnya SRESID. Deteksi ada 
tidaknya heteroskedastisitas dapat dilakukan dengan melihat ada tidaknya pola tertentu pada grafik scaterplot antara SRESID dan ZPRED dimana sumbu y adalah Y yang telah diprediksi dan sumbu $\mathrm{X}$ adalah residual (Y prediksi- $\mathrm{Y}$ sesungguhnya) yang telah distudentized (Imam Ghozali, 2011:139).Hasil uji heterokedastisitas menunjukkan tidak ada pola yang jelas serta titiktitik menyebar di atas dan dibawah angka 0 pada sumbu $\mathrm{Y}$, maka dapat disimpulkan tidak terjadi heteroskedastisitas.

3) Uji Hipotesis

Tahap selanjutnya dalam penelitian ini adalah analisis pengujian hipotesis penelitian. Pengujian hipotesis ini menggunakan analisis regresi linear sederhana dan analisis jalur (path analysis)

\section{HASIL PENELITIAN DAN PEMBA-} HASAN

\section{Hasil Penelitian}

a. Pengaruh Budaya Organisasi terhadap Kinerja Pegawai Bagian Keuangan Organisasi Sektor Publik

Pengujian hipotesis yang pertama dilakukan dengan uji regresi linear sederhana. Nilai regresi diketahui dari hasil perhitungan dengan SPSS Statistics 13.0.

Pengaruh Budaya Organisasi terhadap kinerja pegawai bagian keuangan dapat dilihat dari r Square yaitu sebesar 0,326. Hal ini berarti bahwa pengaruh Budaya Organisasi terhadap Kinerja Pegawai Bagian Keuangan sebesar $32,6 \%$ sedangkan sisanya $67,4 \%$ dipengaruhi oleh faktorfaktor lain yang tidak diteliti dalam model regresi.

b. Pengaruh Gaya Kepemimpinan terhadap Kinerja Pegawai Bagian Keuangan Organisasi Sektor Publik

Hipotesis yang kedua dalam penelitian ini adalah terdapat pengaruh positif Gaya Kepemimpinan dengan Kinerja Pegawai Bagian Keuangan. Teknik analisis untuk menguji hipotesis kedua menggunakan analisis regresi linear sederhana. Perhitungan uji hipotesis ini menggunakan program SPSS Statistics 13.0.

Pengaruh Gaya Kepemimpinan terhadap Kinerja Pegawai bagian keuangan dapat dilihat dari r Square yaitu sebesar 0,364. Hal ini berarti bahwa Budaya Organisasi terhadap Kinerja Pegawai Bagian Keuangan sebesar $36,4 \%$ sedangkan sisanya $63,6 \%$ dipengaruhi oleh faktor-faktor lain yang tidak diteliti dalam model regresi. 


\section{JURNAL NOMINAL / VOLUME IV NOMOR 1 / TAHUN 2015}

c. Pengaruh Budaya Organisasi terhadap Kinerja Pegawai Bagian Keuangan Organisasi Sektor Publik melalui Motivasi Kerja

Hipotesis yang ketiga dalam penelitian ini adalah terdapat pengaruh positif Budaya Organisasi terhadap Kinerja Pegawai bagian keuangan organisasi sektor publik melalui Motivasi Kerja. Teknik analisis untuk menguji hipotesis kelima menggunakan Path Analysis. Perhitungan uji hipotesis ini menggunakan program SPSS Statistics 13.0.

Nilai thitung 3,103 lebih besar dari $t_{\text {tabel }}$ 1,985 dengan tingkat signifikansi 0,05 yaitu sebesar 1,985 dan memiliki koefisien mediasi 0,135 signifikan yang berarti ada pengaruh mediasi. Dari hasil perhitungan tersebut, maka dapat diambil kesimpulan bahwa pengaruh mediasi pada penelitian ini positif dan signifikan. Terlihat bahwa nilai koefisen pengaruh tidak langsung lebih kecil daripada pengaruh langsung secara signifikan berarti Motivasi Kerja dalam memediasi pengaruh Budaya Organisasi terhadap Kinerja Pegawai bagian keuangan itu lemah. Dapat disimpulkan bahwa terdapat pengaruh positif antara Budaya Organisasi terhadap Kinerja Pegawai bagian keuangan melalui Motivasi Kerja sehingga hipotesis keempat dapat diterima.

d. Pengaruh Gaya Kepemimpinan terhadap Kinerja Pegawai Bagian Keuangan Organisasi Sektor Publik melalui Motivasi Kerja

Hipotesis yang keempat dalam penelitian ini adalah terdapat pengaruh positif Gaya Kepemimpinan terhadap Kinerja Pegawai bagian keuangan organisasi sektor publik melalui Motivasi Kerja. Teknik analisis untuk menguji hipotesis kelima menggunakan Path Analysis. Perhitungan uji hipotesis ini menggunakan program SPSS Statistics 13.0.

Nilai thitung 0,917 lebih kecil dari $t_{\text {tabel }}$ dengan tingkat signifikansi 0,05 yaitu sebesar 1,985 dan memiliki koefisien mediasi 0,251 signifikan yang berarti ada pengaruh mediasi. Dari hasil perhitungan $\mathrm{t}$ tersebut, maka dapat diambil kesimpulan bahwa pengaruh mediasi pada penelitian ini positif dan signifikan. Terlihat bahwa nilai koefisen pengaruh tidak langsung lebih kecil daripada pengaruh langsung secara signifikan berarti Motivasi Kerja dalam memediasi pengaruh Gaya Kepemimpinan terhadap Kinerja Pegawai bagian keuangan lemah. Dapat disimpulkan bahwa terdapat pengaruh 


\section{JURNAL NOMINAL / VOLUME IV NOMOR 1 / TAHUN 2015}

positif antara Gaya Kepemimpinan terhadap Kinerja Pegawai bagian keuangan melalui Motivasi Kerja sehingga hipotesis keempat dapat diterima.

\section{Pembahasan}

Penelitian ini bertujuan untuk mengetahui pengaruh Budaya Organisasi dan Gaya Kepemimpinan terhadap Kinerja Pegawai Bagian Keuangan. Hasil uji hipotesis pertama menunjukkan bahwa hasil pengujian $\mathrm{H} 1$ menunjukkan adanya pengaruh positif antara Budaya Organisasi dengan Kinerja Pegawai bagian keuangan di Pemerintah Kota Tasikmalaya. Hal ini berarti semakin kuat Budaya Organisasi maka semakin baik Kinerja Pegawai bagian keuangan yang dihasilkan pegawai. Hal tersebut diperoleh dari analisis regresi linear sederhana dengan persamaan $\mathrm{Y}=$ $7,952+0,601 X_{1}$. Harga $t_{\text {hitung }}$ sebesar 6,476 dan nilai signifikansi 0,000 , maka dapat diambil kesimpulan bahwa terdapat pengaruh positif dan signifikan Budaya Organisasi terhadap Kinerja Pegawai bagian keuangan.

Hasil uji hipotesis kedua menunjukkan bahwa adanya pengaruh positif antara Gaya Kepemimpinan dengan Kinerja Pegawai bagian keuangan di Pemerintah Kota Tasikmalaya. Hal ini berarti semakin efektif Gaya Kepemimpinan maka semakin baik Kinerja Pegawai bagian keuangan yang dihasilkan pegawai. Hal tersebut diperoleh dari analisis regresi linier sederhana dengan persamaan $\mathrm{Y}=-2,479+1,195 \mathrm{X}_{2}$. Harga $\mathrm{t}_{\text {hitung }}$ sebesar 7,341 dan nilai signifikansi 0,000, maka dapat diambil kesimpulan bahwa terdapat pengaruh positif dan signifikan Gaya Kepemimpinan terhadap Kinerja Pegawai bagian keuangan.

Pengujian H3 menunjukkan adanya pengaruh positif antara Budaya Organisasi dengan Kinerja Pegawai bagian Keuangan melalui Motivasi Kerja. Hipotesis ketiga disini menjelaskan adanya pengaruh tidak langsung yang nilainya lebih tinggi dari pengaruh langsung. Dari hasil perhitungan yang didapat nilai pengaruh tidak langsung lebih kecil dari pengaruh langsung. Hal ini berarti penelitian ini memiliki pengaruh tidak langsung yang lemah. Selanjutnya dari perhitungan $t_{\text {tabel }}>t_{\text {hitung, }}$, besar $t_{\text {hitung }}$ adalah 3,103 dan tabel1,985 dan koefisien mediasi dari Motivasi Kerja sebesar 0,135. Dari perhitungan Path analysis tersebut, dapat disimpulkan bahwa terdapat pengaruh positif dan signifikan antara Budaya Organisasi terhadap Kinerja Pegawai Bagian Keuangan melalui Motiasi Kerja.

Pengujian H5 menunjukkan adanya pengaruh positif dan signifikan antara Gaya Kepemimpinan dengan Kinerja Pegawai bagian Keuangan melalui Motivasi Kerja. Hipotesis kelima disini tidak menjelaskan adanya pengaruh tidak langsung yang nilainya lebih tinggi dari pengaruh langsung namun hasil dari perhitungan $t_{\text {tabel }}>t_{\text {hitung, }}$ 


\section{JURNAL NOMINAL / VOLUME IV NOMOR 1 / TAHUN 2015}

besar $t_{\text {hitung }}$ adalah 0,917 dan $t_{\text {tabel }} 1,985$ dan koefisien mediasi 0,251. Dari perhitungan Path analysis tersebut, dapat disimpulkan bahwa terdapat pengaruh positif dan signifikan antara Gaya Kepemimpinan terhadap Kinerja Pegawai Bagian Keuangan melalui Motivasi Kerja dengan pengaruh tidak langsung yang lemah.

Hasil penelitian ini mendukung penelitian yang dilakukan oleh Rani Mariam (2009) dan M. Hanif Al Rizal (2012). Hasil dari penelitian Rani Mariam (2009) tersebut menyebutkan bahwa Budaya Organisasi berpengaruh positif terhadap Kinerja Karyawan di PT. Asuransi Jasa Indonesia. Hasil dari penelitian M. Hanif Al Rizal (2012) menyebutkan bahwa Budaya Organisasi berpengaruh terhadap Kinerja Karyawan di Rumah Sakit Panti Wilasa “Citarum" Kota Semarang. Hasil penelitian ini juga didukung oleh teori yang menyatakan bahwa Budaya Organisasi sebagai suatu sistem makna bersama yang dianut oleh pegawai yang membedakan organisasi tersebut dengan organisasi yang lain.

Hasil penelitian ini mendukung penelitian yang dilakukan oleh Heri Susanto (2010) yang menyebutkan bahwa Budaya Organisasi berpengaruh positif dan signifikan, dan memberi pengaruh positif ke Kinerja Pegawai bagian keuangan akan tetapi tidak signifikan terhadap Kinerja Karyawan melalui Motivasi Kerja di kantor Pertanahan
Kabupaten Kebumen. Ini berarti bahwa persepsi sebuah budaya oleh pegawai dapat mempengaruhi cara bekerjanya di dalam organisasi karena merasa bahwa lingkungan kerjanya kondusif, saling menghargai dan saling mempercayai dalam melaksanakan tugas, akan tetapi pengaruhnya tidak signifikan.

Hal ini menguatkan penelitian sebelumnya oleh Iqbal Nazili pada tahun (2012) yang menyatakan bahwa Gaya Kepemimpinan berpengaruh positif dan signifikan terhadap Kinerja Karyawan melalui Motivasi Kerja di PT. Garuda Indonesia Kota Semarang. Hasil penelitian ini didukung oleh teori bahwa gaya kepemimpinan serta kebutuhan manusia, termasuk pegawai, penting sekali bagi seorang pemimpin, karena hal tersebut berkaitan dengan Motivasi Kerja.

\section{SIMPULAN DAN SARAN}

\section{Simpulan}

Berdasarkan hasil analisis dan pembahasan mengenai pengaruh Budaya Organisasi dan Gaya Kepemimpinan terhadap Kinerja Pegawai Bagian Keuangan Organisasi Sektor Publik dengan Motivasi Kerja Sebagai Variabel Intervening (Survei Pada Pegawai Pemerintah Kota Tasikmalaya), maka dapat ditarik kesimpulan sebagai berikut:

1. Budaya Organisasi berpengaruh positif terhadap Kinerja Pegawai bagian 


\section{JURNAL NOMINAL / VOLUME IV NOMOR 1 / TAHUN 2015}

keuangan. Hal ini ditunjukkan pada hasil 5. regresi linear sederhana yang memiliki nilai $t_{\text {hitung }}$ sebesar 6,476 yang lebih besar dari $t_{\text {tabel }}$ sebesar 1,985 dan memiliki signifikan sebesar 0,000 atau di bawah 0,05 .

2. Gaya Kepemimpinan berpengaruh positif terhadap Kinerja Pegawai bagian keuangan. Hal ini ditunjukkan pada hasil regresi linear sederhana yang memiliki nilai $t_{\text {hitung }}$ sebesar 7,341 yang lebih besar dari tabel sebesar 1,985 dan memiliki signifikan sebesar 0,000 atau di bawah 0,05 .

3. Motivasi Kerja berpengaruh positif terhadap Kinerja Pegawai bagian keuangan. Hal ini ditunjukkan pada hasil regresi linear sederhana yang memiliki $t_{\text {hitung }}$ sebesar 5,493 yang lebih besar dari $t_{\text {tabel }}$ sebesar 1,985 dan memiliki signifikan sebesar 0,000 atau di bawah 0,05 .

4. Budaya Organisasi berpengaruh positif terhadap Kinerja Pegawai bagian keuangan yang dimediasi oleh Motivasi Kerja. Adanya pengaruh mediasi yang lemah disini dapat ditunjukkan dengan adanya pengaruh tidak langsung sebesar 0,135 yang lebih kecil dibandingkan dengan pengaruh langsung sebesar 0,465 . Selain itu, dari nilai $\mathrm{t}$ hitung 3,103 lebih besar dari $\mathrm{t}$ tabel dengan tingkat signifikansi 0,05 yaitu sebesar 1,985.
Gaya Kepemimpinan berpengaruh positif terhadap Kinerja Pegawai bagian keuangan yang dimediasi oleh Motivasi Kerja. Pengaruh mediasi ini lemah dilihat dari pengaruh tidak langsung sebesar 0,251 yang lebih kecil dibandingkan dengan pengaruh langsung sebesar 0,944. Selain itu, dari nilai $t_{\text {hitung }}$ 0,917 lebih kecil dari tabel dengan tingkat signifikansi 0,05 yaitu sebesar 1,985.

\section{Saran}

Saran-saran yang dapat diberikan berkaitan dengan pengaruh Budaya Organisasi dan Gaya Kepemimpinan terhadap Kinerja Pegawai Bagian Keuangan Organisasi Sektor Publik dengan Motivasi Kerja Sebagai Variabel Intervening (Studi Kasus Pada Pegawai Pemerintah Kota Tasikmalaya), yaitu :

1. Bagi Pegawai Pemerintah Kota Tasikmalaya

a. Organisasi diharapkan memiliki sistem akuntansi yang memastikan bahwa transaksi yang tercatat mencakup kriteria antara lain sah, diotorisasi, diklarifikasi, dilaporkan pada periode yang tepat, dinilai dengan benar, diikhtisarkan dengan jelas, dan dapat menyediakan jejak audit yang dapat membantu meningkatkan kedisiplinan kerja pegawai bagian keuangan tanpa harus diawasi. 


\section{JURNAL NOMINAL / VOLUME IV NOMOR 1 / TAHUN 2015}

b. Organisasi diharapkan dapat menciptakan aliran komunikasi angket yang jawabannya telah tersedia. dengan reputasi dan kredibilitas yang tinggi dari semua tingkatan di dalam organisasi

c. Pemimpin diharapkan lebih transparan dalam segala hal yang berkaitan organisasi

d. Organisasi diharapkan dapat melakukan perbaikan insentif, tunjangan, kesempatan promosi, kesempatan mengikuti pendidikan dan latihan, peningkatan kesadaran terhadap tugas dan tanggungjawab sesuai dengan fungsinya masingmasing, adanya reward and funishment, adanya kesesuaian penempatan antara pendidikan dengan jabatan yang diduduki, dan lingkungan kerja yang kondusif.

2. Bagi Peneliti Selanjutnya

a. Peneliti selanjutnya dapat melakukan penelitian pada lingkup yang lebih luas, yaitu bukan hanya pada satu Pemerintah Kota saja namun beberapa Pemerintah Kota/Kabupaten.

b. Peneliti selanjutnya disarankan untuk menambah metode lain dalam meneliti Kinerja Pegawai bagian keuangan, misalnya wawancara mendalam terhadap pegawai, sehingga informasi yang diperoleh lebih bervariasi dan lengkap daripada

\section{DAFTAR PUSTAKA}

A.A. Anwar Prabu Mangkunegara. (2013). Manajemen Sumber Daya Manusia Perusahaan. Bandung: PT. Remaja Rosdakarya.

Ali Muhson. (2005). Modul SPSS. Yogyakarta: FE UNY.

Daft, Richard L. (2010). Era Baru Manajemen. (Penerjemah: Tita Maria Kanita). Edisi ke 9. Jakarta: Salemba Empat.

Davis Keith \& Newstrom, Jhon W. (2005). Perilaku dalam Organisasi. (Ahli Bahasa: Agus Dharma) Edisi ke 7. Jakarta: Erlangga.

Deddi Nordiawan. (2006). Akuntansi Sektor Publik. Jakarta: Salemba Empat.

Heri Susanto. (2010). "Analisis Pengaruh Kepemimpinan dan Budaya Kerja dengan Motivasi sebagai Variabel Intervening terhadap Kinerja Karyawan di Kantor Pertanahan Kabupaten Kebumen". Tesis. Magister Sekolah Tinggi Pertanahan Nasional (STPN) Yogyakarta.

Husein Umar. (2011). Metode Penelitian untuk Skripsi dan Tesis Bisnis. Edisi ke 2. Jakarta: PT. Raja Grafindo Persada. Irfan Fahmi. (2010). Manajemen Kinerja Teori dan Aplikasi. Bandung: Alfabeta. 


\section{JURNAL NOMINAL / VOLUME IV NOMOR 1 / TAHUN 2015}

Imam Gozali. (2011). Aplikasi Analisis Multivariate dengan Program IBM SPSS 19. Edisi ke 5. Semarang: Universitas Diponegoro.

Indra Bastian. (2006). Akuntansi Sektor Publik: Suatu Pengantar. Jakarta: Erlangga.

Iqbal Nazili. (2012). "Pengaruh Gaya Kepemimpinan dan Iklim Orgaisasi terhadap Kinerja Karyawan: Motivai kerja Sebagai Variabel Intervening (Studi Pada Karyawan PT. Garuda Indonesia Kota Semarang)". Skripsi. Fakultas Ekonomika dan Bisnis Universitas Diponegoro.

John M. Ivancevich, Robert Konopaske, \& Michael T. Matteson. (2007). Perilaku dan Manajemen Organisasi. Edisi ke 7. Jakarta: Erlangga

M. Hanif Al Rizal. (2012). "Pengaruh Budaya Organisasi Dan Kepuasan Kerja Terhadap Kinerja Karyawan (Studi Pada Rumah Sakit Panti Wilasa "Citarum" Kota Semarang)". Skripsi. Fakultas Ekonomika dan Bisnis Universitas Diponegoro.

Makmuri Muchlas. (2005). Perilaku Organisasi. Yogyakarta: Gajah Mada University Press.

Malayu S. P. Hasibuan. (2007). Organisasi dan Motivasi dasar peningkatan Produktivitas. Edisi ke 5. Jakarta: PT. Bumi Aksara.
Mardiasmo. (2004). Akuntansi Sektor Publik. Yogyakarta: Andi.

Miftah Thoha. (2007). Kepemminan Dalam Manajemen. Jakarta: PT. Raja Grafindo Persada.

Moh. Pabundu Tika. (2010). Budaya Organisasi dan Peningkatan Kinerja Perusahaan. Jakarta: PT. Bumi Aksara. Moehriono. (2012). Pengukuran Kinerja Berbasis Kompetensi. Jakarta: PT. Raja Grafindo Persada.

Pasolong Harbani. (2008). Kepemimpinan Birokrasi. Bandung: Alfabeta.

Pemerintah Kota Tasikmalaya. (2013). Penilaian Kinerja UKPP Bagian Pertanian Tingkat Provinsi Jawa Barat Untuk Penghargaan Abdibakti Tani 2013. Diambil dari http://www.tasikmalaya.go.id pada tanggal 20 November 2013.

Rani Mariam. (2009). "Pengaruh Gaya Kepemimpinan dan Budaya Organisasi terhadap Kinerja Karyawan melalui Kepuasan Kerja Karyawan sebagai Variabel Intervening (Studi Pada Kantor Pusat PT. Asuransi Jasa Indonesia)". Tesis. Magister Manajemen Universitas Diponegoro.

Regina Aditya Reza. (2010). "Pengaruh Gaya Kepemimpinan, Motivasi dan Disiplin Kerja terhadap Kinerja Karyawan PT Sinar Santosa Perkasa Banjarnegara". Skripsi. Fakultas Ekonomi Universitas Diponegoro. 
Republik Indonesia. (2009). UU No. 25

Tahun 2009 Tentang Pelayanan

Publik, Jakarta.

Republik Indonesia. (2008). UU No. 14

Tahun 2008 Tentang Keterbukaan

Informasi Publik, Jakarta.

Sondang P. Siagian. (2003). Teori dan

Praktek Kepemimpinan. Jakarta:

Penerbit Rineka Cipta Jakarta.

Sugiyono. (2012). Metode Penelitian

Administrasi dan $R \& D$. Bandung:

Alfabeta. (2009). Statistik untuk Penelitian.

Bandung: Alfabeta.

Sutrisno Hadi. (2004). Analisis Regresi.

Yogyakarta: Andi Offset.

Suwatno \& Donni Juni Priansa. (2011).

Manajemen SDM dalam Organisasi

Publik dan Bisnis. Bandung: Alfabeta.

Suyadi Prawirosentono. (2008). Akuntansi

Kebijakan Kinerja Karyawan.

Yogyakarta: BPFE.

Uma Sekaran. (2006). Metode Penelitian untuk Bisnis. Edisi ke 4. Jakarta: Salemba Empat.

Veitzhal Rivai dan Deddy Mulyadi. (2013). Kepemimpinan Dan Perilaku Organisasi. Jakarta: PT. Raja Grafindo Persada. 